\title{
Article
}

\section{To what extent have relaxed eligibility requirements and increased generosity of disability benefits acted as disincentives for employment? A systematic review of evidence from countries with well-developed welfare systems}

Barr, Ben, Clayton, Stephen, Whitehead, Margaret, Thielen, Karsten, Burstrom, Bo, Nylen, Lotta and Dahl, Espen

Available at https://clok.uclan.ac.uk/11105/

Barr, Ben, Clayton, Stephen orcid iconORCID: 0000-0003-2823-1495, Whitehead, Margaret, Thielen, Karsten, Burstrom, Bo, Nylen, Lotta and Dahl, Espen (2010) To what extent have relaxed eligibility requirements and increased generosity of disability benefits acted as disincentives for employment? A systematic review of evidence from countries with welldeveloped welfare systems. Journal of Epidemiology and Community Health, 64 (12). pp. 1106-1114. ISSN 0143-005X

It is advisable to refer to the publisher's version if you intend to cite from the work.

For more information about UCLan's research in this area go to http://www.uclan.ac.uk/researchgroups/ and search for <name of research Group>.

For information about Research generally at UCLan please go to http://www.uclan.ac.uk/research/

All outputs in CLoK are protected by Intellectual Property Rights law, including

CLoK

Central Lancashire online Knowledge www.clok.uclan.ac.uk

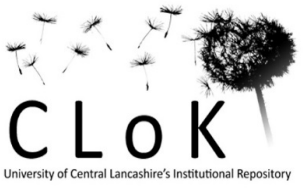




\section{CLoK}

Central Lancashire online Knowledge www.clok.uclan.ac.uk 
4023 words excluding headings, tables, appendices, references (9056 total)

Draft ( BB 1/02/2010)

To what extent have improvements in level or eligibility of disability benefits acted as disincentives for employment? A systematic review of evidence from countries with welldeveloped welfare systems.

Ben Barr, Stephen Clayton, Margaret Whitehead, Karsten Thielen, Bo Burström, Lotta Nylen, Espen Dahl

\section{Introduction}

Dramatic rises in the number of people claiming disability benefits in several OECD countries over recent decades have lead to concerns about the social and economic exclusion of disabled people and the costs of income support for these groups [1-5]. Evidence from the UK and Sweden indicates a social gradient in the employment of chronically ill and disabled people, with employment rates declining with declining socioeconomic status [6-7]. Worklessness increases the risk of poverty and social exclusion which may further damage health and exacerbate health inequalities.

One aim of disability policy is to provide adequate income security to people with a health condition or impairment when they are too illunable to work. Economists have long debated the effects of welfare programmes, with some arguing that the level of provision of income security benefits themselves-acts as a disincentive to labour force participation [8]. Several_authors in the US-have concluded that the increase in the availability of disability benefits is responsible for most of the decline in labour force participation amongst older men in that countrythe US [9-11]. These econometric studies have ${ }_{L}$ however ${ }_{L}$ been criticised for inaccurately estimating the disincentive effects of disability benefits [12-15].

The empirical evidence that does exist to supportsupports the hypothesis that disability benefits are major disincentives for work largely comes from studies in the United States (US)comes largely from studies in the US., but it would be unsound to generalise from the US context to countries with more extensive fare systems. Compared to more extensive welfare systems, however, The consequences for disabled people of not being employed are very different in the US where there are fewer safety nets, no universal health care system, and employer-provided health insurance is often provided through an employer andthat is lost when a person loses that employment. Thus, it is would be unwise to generalise to other welfare systems from the US experience. This paper aims 
to There is a need to-synthesise the evidence on the question of employment disincentives in the context of advanced welfare systems, which is the aim of this paper.

We conducted a systematic review of the evidence from 5 countries with well-developed welfare and universal healthcare systems to answer the following review question: "To what extent do the generosity or eligibility requirements of disability benefit programmes affect labour market participation?" These countries have implemented numerous policies over the past 30 years to alter benefit generosity and eligibility (see Appendix 1), providing an opportunity to exploit these natural policy experiments. More recently, policy makers in these countries have begun to experiment with reducing the generosity and narrowing the eligibility criteria for these benefits, on the assumption that this will increase the employment of people with chronic illness and disabilities. This strategy underpins the introduction of the Employment Support Allowance in the UK in 2008, the 2008 reforms of the Swedish Sickness Insurance System, the 2003 reforms of disability benefits in Denmark and the 2004 disability benefit reforms in Norway [3-5, 16]. Whilst there has been a traditional review assessing the factors that have contributed to recent increases in disability benefits recipients in the UK [17], to our knowledge this is the first systematic review to address this issue and to take into account the relevance of the welfare system context.

\section{Methods}

Through our search and selection strategy we sought to identify all empirical studies from Canada, Denmark, Norway, Sweden and the UK that addressed the research question given above. We restricted our review to studies from these countries as they have sufficiently similar social welfare systems and policy contexts for cross-country policy learning to be relevant.

\section{Searches}

We searched 13 databases (Appendix 2) from 1970 to October 2008. In addition grey literature searches were conducted on 12 relevant governmental and non-governmental organisational web sites (Appendix 2). This included a supplemental search at the Library of the University of Copenhagen. A comprehensive list of linked search terms was used, with terms associated with the policy, the population and the outcome (Appendix 3). Websites were searched using a search engine which allowed for site specific searches with multiple search terms linked with Boolean commands [18].

\section{Selection}


The searches identified 3077 potentially relevant studies. Following selection using the inclusion criteria in Table 1 and validity assessment detailed in Appendix 2, a total of 16 studies were included in the final review (figure 1).

We defined disability benefits as, "state supported income replacement benefits paid to individuals out of the labour market for over 3 months due to health problems or disabilities". We therefore excluded studies that primarily investigated the effect of economic incentives on short term sickness absence. We also excluded studies which did not investigate the effect of disability benefit programmes on movement into or out of the labour market, e.g. those that only analysed movement between different benefit schemes. We defined eligibility requirements as any criteria or procedures the applicant needs to meet, or undergo in order to be eligible for disability benefits.

Table 1. Criteria used to select studies for data collection and validity assessment

\begin{tabular}{l} 
Study Design. All quantitative study designs. \\
\hline Participants/ population: Working age (16-69) people or a subset of this population in Canada, \\
Denmark, Norway, Sweden or the UK, from 1970 to the 2008 \\
Intervention. Changes to, or differences in, the generosity and/or eligibility requirements of \\
disability benefits. \\
-Effect on the probability of being in employment and/or being on disability benefits. \\
-Length of time on disability benefits. \\
-length of time off work or not in employment.
\end{tabular}

The lead reviewer excluded papers that were considered irrelevant, based on their titles and abstracts. The remaining studies were then evaluated separately by two reviewers against the inclusion criteria and validity assessment. A standardised form was used to collect data on the key characteristics of each study and carry out the validity assessment. Where results of multiple models are given in the papers reviewed, the results of the fullest or final model are presented here.

\section{Validity Assessment}

Econometric studies were the only study type identified through this review. There are no standard tools available for the appraisal of econometric studies[19]. After consultation with an expert in synthesis of econometric studies (N.Rice, York University), a simple quality appraisal framework was developed using core epidemiological principles for assessing validity (Appendix 2) [20-22]. 
A total of 28 studies underwent validity assessment, of which 12 were excluded by the process [2333]. The excluded studies had adopted a similar strategy to that criticised by Bound (1989). Whilst they used regression models to compare the labour force participation of those with different disability benefit levels, the difference in disability benefit levels were due to the application of the benefit rules rather than a change in those rules resulting from policy decisions. The variation in benefit levels in these studies was therefore determined to a large part by other factors such as age, level of disability, prior earnings or number of dependants, each of which would have a direct independent effect on labour market participation. Bound $(1989,1991)$ argues that this analytical strategy significantly overestimates the impact of disability benefits on labour market attachment $[13,15]$

\section{Results}

Sixteen studies were included from 4 countries: 8 from Canada, 5 from the UK, 2 from Sweden and one from Norway. No studies from Denmark met the inclusion criteria. The studies included investigated both changes in benefit generosity and eligibility criteria (see Table 2). The main findings are presented for each country separately to take into consideration the country policy and labour market context.

Table 2: TThe typologyes of policy changes investigated by studies included in the reviewevaluated by studies included in the review

\begin{tabular}{|l|l|l|}
\hline Type of policy changes investigated & Number of studies & \\
\hline Differences in benefit generosity only & 9 & {$[34-42]$} \\
\hline Changed eligibility requirements only & 3 & {$[43-45]$} \\
\hline $\begin{array}{l}\text { Both changes in eligibility requirements and benefit generosity } \\
\text { as separate parameters in the same model }\end{array}$ & 2 & {$[34,46]$} \\
\hline $\begin{array}{l}\text { Policy change that included a combination of changes to } \\
\text { eligibility requirements and benefit generosity }\end{array}$ & 2 & {$[47-48]$} \\
\hline
\end{tabular}

\section{Studies investigating Canadian policy changes}

Seven of the eight studies from Canada assessed the impact of changes in the Canadian/ Quebec Pension Plan (CPP/ QPP) [34-35, 37, 43-44, 46, 49], and one study investigated the impact of variations in benefits from various sources [36] (see Table 2). The majority of studies (6/8) investigated effects on men only and most only reported on people over the age of 45 (7/8). Two of 
these studies investigated changed eligibility requirements [43-44], 4 investigated benefit generosity $[35-37,49]$ and 2 investigated both [34, 46].

Of the four papers that investigated changes in the CPP/QPP eligibility requirements, one of these found that there was no association between increased rejection rates (indicating more stringent assessment criteria) and labour market participation[44]. Two studies found that some periods of relaxed eligibility were significantly associated with an increase in labour market participation, whilst others had no significant effect. The fourth study found that a relaxation of eligibility criteria, that allowed assessors to take into account local labour market conditions in deciding on elligibilityeligibility, was significantly associated with a decrease in employment [43].

Of the six Canadian papers that investigated the effect of differences in benefit replacement rates or benefit levels, four reported that higher benefit levels or replacement rates during the late $1980 \mathrm{~s}$ and early 1990s were associated with lower male employment [34-37] . These studies did not control for education level $[34,36]$ and health status [35, 37]. One of these studies concluded that although the level of disability benefits did discourage labour force participation, the disincentive effects of low wages had a much greater effect [36]. Two studies found that changes in benefit levels had no significant effect $[46,49]$. One of these investigated changes that occurred to benefit levels in 1973 [49] and the other investigated the effect of changes in replacement rates between 1983 and 1997 [46]. This second study found that the effect of changing replacement rates on women was in the opposite direction to that hypothesised by the study: higher replacements rates were associated with higher levels of female labour market participation $(p=0.052)$. 
Table 3. Studies investigating policy changes and differences between jurisdictions in Canada

\begin{tabular}{|c|c|c|c|c|c|c|}
\hline Author & Population & Study type & $\begin{array}{l}\text { Description of policy under } \\
\text { analysis }\end{array}$ & Result - regression coefficient (p-value) & Comments & VA \\
\hline $\begin{array}{l}\text { Campolieti } \\
\text { (2004)[49] }\end{array}$ & $\begin{array}{l}\text { Men aged 45- } \\
64\end{array}$ & $\begin{array}{l}\text { Differences in } \\
\text { differences with } \\
\text { individual data }\end{array}$ & $\begin{array}{l}1973 \text { policy change increasing } \\
\text { QPP benefits by \$50(CAD) a } \\
\text { month. }\end{array}$ & $\begin{array}{l}\text { Linear regression of policy change on non- } \\
\text { employment. } \\
45-64 \text { year olds: } 0.008(\mathrm{p}=0.3) \\
45-59 \text { year olds: } 0.001(\mathrm{p}=0.48)\end{array}$ & $\begin{array}{l}\text { The authors concluded that all the difference-in-difference estimates } \\
\text { suggested that the disincentive effects associated with disability } \\
\text { benefits would be economically small and not statistically significant } \\
\text { at that time. No control for health status or labour market conditions. }\end{array}$ & 13 \\
\hline $\begin{array}{l}\text { Campolieti and } \\
\text { Goldenberg, } \\
\text { (2007)[44] }\end{array}$ & $\begin{array}{l}\text { Men and } \\
\text { Women } 45-64 \\
\text { years old }\end{array}$ & $\begin{array}{l}\text { Differences in } \\
\text { differences with } \\
\text { individual data }\end{array}$ & $\begin{array}{l}\text { Changes in the eligibility and } \\
\text { medical screening criteria } \\
\text { occurring in mid 1990s and } \\
\text { differences between QPP and } \\
\text { CPP and between CPP regions. }\end{array}$ & $\begin{array}{l}\text { Linear regression of benefit rejection rates on non- } \\
\text { participation } \\
\text { Men } 0.646(p=0.166) \\
\text { Women } 0.02(p=0.297)\end{array}$ & $\begin{array}{l}\text { The authors concluded that they did not find a statistically significant } \\
\text { negative relationship between denial rates and the labour force non- } \\
\text { participation of older men and women. Health status not sufficiently } \\
\text { controlled. }\end{array}$ & 13 \\
\hline $\begin{array}{l}\text { Harkness (1993) } \\
\text { [36] }\end{array}$ & $\begin{array}{l}\text { Prime aged } \\
\text { men with self } \\
\text { reported } \\
\text { disability }\end{array}$ & $\begin{array}{l}\text { Cross-sectional } \\
\text { survey }\end{array}$ & $\begin{array}{l}\text { Level of expected disability } \\
\text { pension (combination of CPP, } \\
\text { WCB, private insurance } \\
\text { payments) }\end{array}$ & $\begin{array}{l}\text { Logistic Regression of benefit level on labour force } \\
\text { participation } \\
-0.00019(p=0.006) \\
\text { Elasticity=- } 2.03\end{array}$ & $\begin{array}{l}\text { The authors concluded that disability benefits did discourage work, } \\
\text { but the disincentive effects of low wages were greater. Level of } \\
\text { education not controlled. }\end{array}$ & 11 \\
\hline Gruber (2000)[35] & Men 45-59 & $\begin{array}{l}\text { Differences in } \\
\text { differences with } \\
\text { individual data }\end{array}$ & $\begin{array}{l}1987 \text { increase in the CPP benefit } \\
\text { level to bring it to the level of the } \\
\text { QPP }\end{array}$ & $\begin{array}{l}\text { Logistic regression of policy and replacement rate on } \\
\text { non-labour market participation in two separate } \\
\text { models } \\
\text { Policy change }=0.15(\mathrm{OR}=1.16)(\mathrm{p}=0.02) \\
\text { Replacement rate: } 1.344(\mathrm{OR}=3.8)(\mathrm{p}=0.009) \\
\text { Elasticity }=0.28\end{array}$ & $\begin{array}{l}\text { The authors concluded that both models showed a significant effect of } \\
\text { increases in benefit levels and the replacement rate in reducing labour } \\
\text { market participation. Health status not controlled. }\end{array}$ & 11 \\
\hline $\begin{array}{l}\text { Campolieti, } \\
\text { (2003)[43] }\end{array}$ & $\begin{array}{l}\text { Men aged 45- } \\
65\end{array}$ & $\begin{array}{l}\text { Differences in } \\
\text { differences with } \\
\text { individual data }\end{array}$ & $\begin{array}{l}1989 \text { change in CPP eligibility } \\
\text { requirmentsrequirements } \\
\text { permitting the use of } \\
\text { socioeconomic conditions } \\
\text { (e.ge.g. regional unemployment) } \\
\text { in assessing eligibility for } \\
\text { disability benefits }\end{array}$ & $\begin{array}{l}\text { Linear regression on labour market participation } \\
0.015(p=0.016)\end{array}$ & $\begin{array}{l}\text { The authors concluded that thethat the relaxation in eligibility } \\
\text { requirements reduced the labour supply of older men in Canada by } \\
1.5 \% \text {. Health status, wages and benefit levels not controlled. }\end{array}$ & 11 \\
\hline $\begin{array}{l}\text { Campolieti, (2001b) } \\
\text { [46] }\end{array}$ & $\begin{array}{l}\text { Men and } \\
\text { Women 45-65 }\end{array}$ & $\begin{array}{l}\text { Differences in } \\
\text { differences with } \\
\text { ecological data }\end{array}$ & $\begin{array}{l}\text { 1. Average replacement rate } \\
\text { between } 1983 \text { and } 1997 \\
\text { Z.Retzed2. Relaxed CPP } \\
\text { eligibility criteria between } 1987 \\
\text { and } 1994 \\
\text { 3. Relaxed QPP eligibility } \\
\text { between } 1993 \text { and } 1997 \\
\text { 4. QPP early retirement provision }\end{array}$ & $\begin{array}{l}\text { Linear regression on labour force participation } \\
\text { Men } \\
\text { 1:Men: }-0.2450(\mathrm{p}=0.9) \text {,Women: } 0.1341(\mathrm{p}=0.052) \\
\text { 2: Men: } 0.0251(\mathrm{p}=0.04) \text {, Women: }-0.0088(\mathrm{p}=0.9) \\
\text { 3: Men: }-0.0082(\mathrm{p}=0.2) \text {, Women: } 0.0142(\mathrm{p}=0.02) \\
\text { 4: Men: }-0.0478(\mathrm{p}<0.001) \text {, Women: } 0.0008(\mathrm{p}=0.4)\end{array}$ & $\begin{array}{l}\text { The authors concluded that some of these estimates did not support } \\
\text { the hypothesis that looser eligibilitit rules decrease participation rates } \\
\text { since they were not statistically significant or did not have the } \\
\text { expected sign. The change in replacement rate was not significant for } \\
\text { men in the full model. Increasing replacement rates were associated } \\
\text { with increased employment in women in the full model, although this } \\
\text { was not significant. Education level was not controlled for in the } \\
\text { models and the health status control was inadequate. }\end{array}$ & 10 \\
\hline $\begin{array}{l}\text { Campolieti(2001)[34 } \\
\text { ] }\end{array}$ & $\begin{array}{l}45-64 \text { year old } \\
\text { men }\end{array}$ & $\begin{array}{l}\text { Differences in } \\
\text { differences with } \\
\text { ecological data }\end{array}$ & $\begin{array}{l}\text { 1. Replacement rate of C/QPP } \\
\text { benefits } \\
\text { 2. Period of relaxed eligibility in } \\
\text { CPP (1987-1994). }\end{array}$ & $\begin{array}{l}\text { Linear regression on labour force participation } \\
1:-0.2171(p=0.004) \\
2: 0.0149(p=0.004)\end{array}$ & $\begin{array}{l}\text { The relaxed eligibility requirements in the CPP disability program did } \\
\text { not have the expected sign in any of the regressions. The replacement } \\
\text { rate was significantly sassociated with a decline in participation rates. } \\
\text { However, these coefficient estimates were smaller and not statistically } \\
\text { significant when the year specific effects were used instead of the } \\
\text { linear time trend. Education level was not controlled for in the models } \\
\text { and the health status control (regional mortality rate) was inadequate. }\end{array}$ & 9 \\
\hline Maki (1993) [37] & $\begin{array}{l}45-65 \text { year old } \\
\text { Men }\end{array}$ & $\begin{array}{l}\text { Time series } \\
\text { ecological }\end{array}$ & $\begin{array}{l}\text { 1. Average monthly } \\
\text { benefit payments in QPP/CPP as } \\
\text { a ratio with wages } \\
\text { 2. Difference between QPP and }\end{array}$ & $\begin{array}{l}\text { Linear regression on labour market participation } \\
1:-0.2(p<0.001) \\
2: 0.102(p<0.001)\end{array}$ & $\begin{array}{l}\text { The authors concluded that higher rates of benefits were significantly } \\
\text { associated with lower employment. Health status and education level } \\
\text { not controlled. }\end{array}$ & 8 \\
\hline
\end{tabular}




\section{Studies investigating UK policy changes}

Five studies of UK benefit policy change were reviewed (Table 3). Two of the studies used the British Household Panel Survey (BHPS) to assess the impact of the 1995 Incapacity to Work Act (IWA) [4748]. This policy included a reduction in the level of benefits paid, particularly for older age groups, and a tightening of eligibility requirements. Disney et al (2003) did not detect a significant effect from the reforms on the employment of older men with poor health [48]. In contrast, Clasen et al (2006) concluded that the reforms made transitions from inactivity into employment more likely for 25-49 year old men and reduced the flow of older men (aged 50-64) from employment into long term sickness. Neither of these studies controlled for changes in wage levels and Clasen et al (2006) did not control for changes in health status.

Two studies used aggregate time series data to investigate the effect, on labour market participation, of changes in benefit levels and replacement rates between the early 1980s and the end of the 1990s [39] [40]. Benefit levels had been increasing up to the 1995 reform, which then decreased the benefits paid to older workers considerably. They find that replacement rates[39] and benefit levels[40] were negatively associated with labour force participation. However, neither study controlled for health status and labour market conditions. When separate age trends were included in the model in Bell and Smith's (2004) paper the overall effect was no longer significant[39]. Both studies found that that the negative effect of benefit levels on employment was larger for people with no qualifications. Using a model that did not include replacement rates, Faggio and Nickell (2005) found significant negative effects on labour market participation resulting from falls in regional wages in low level occupations in relation to national wage levels.

\section{Another UK study analysed aggregate data from 1979 to 1984 and found that higher average} replacement rates were associated with increasing numbers of people receiving benefits[38]. However, the model used did not control for health status or labour market conditions. Given that this period in the UK was one of rapidly rising national unemployment, this would need to be taken into consideration when interpreting the results. In a seperateseparate analysis with using cross sectional data they showindicated that unemployment was the dominant factors influencing disability benefit receipt, with higher unemployment levels in an area associated with higher disability benefit receipt.
Commented [SPC1]: Not sure you need the initials as you never refer to it again!

Commented [SPC2]: Should this be onto long term sickness benefits - it's not making them sick as such is it?
Commented [SPC3]: This is a bit confusing - did it decrease the benefit level only for older groups or for everyone but the decrease was more significant for older groups? 
Table 4 Studies from the UK on benefit changes

\begin{tabular}{|c|c|c|c|c|c|c|}
\hline Author & Population & Study type & Description of policy under analysis & Result - regression coefficient (p-value) & Comments & VA \\
\hline $\begin{array}{l}\text { Disney, R, } \\
\text { Emmerson,C } \\
\text { Wakefield, } \\
M[48]\end{array}$ & $\begin{array}{l}\text { 50-64 year } \\
\text { olds }\end{array}$ & $\begin{array}{l}\text { Interrupted times } \\
\text { series with panel } \\
\text { data }\end{array}$ & $\begin{array}{l}\text { The introduction of the Incapacity to work Act in } \\
1995 \text { replacing invalidity benefits (IVB) with } \\
\text { Incapacity Benefit (IB). IB was not available to people } \\
\text { over state pension age, Eligibility conditions were } \\
\text { tightened, those claiming IB no longer received an } \\
\text { additional pension, based on earnings history, this } \\
\text { meant that benefit level for older workers reduced } \\
\text { by about 37\%. }\end{array}$ & $\begin{array}{l}\text { Fixed effects logistic regression of policy change on } \\
\text { employment } \\
0.10(\mathrm{OR} 1.11)(\mathrm{p}=0.3)\end{array}$ & $\begin{array}{l}\text { The authors concluded that the weak results } \\
\text { may reflect either a weak, or indeed no, } \\
\text { relationship between the policy change and } \\
\text { employment. Did not control for changes in } \\
\text { wages }\end{array}$ & 13 \\
\hline $\begin{array}{l}\text { Clasen } \\
\text { J;Davidson } \\
\text { J;Granssmann } \\
\text { H;Mauer } \\
\text { A;[47] }\end{array}$ & $\begin{array}{l}\text { men 25-64 } \\
\text { year old }\end{array}$ & $\begin{array}{l}\text { Interrupted times } \\
\text { series with panel } \\
\text { data }\end{array}$ & $\begin{array}{l}\text { Introduction of Incapacity for Wwork Aact (IWA) } \\
1995, \text { which tightened eligibility criteria and had } \\
\text { effect of reducing benefit level for older workers. }\end{array}$ & $\begin{array}{l}\text { Hazard model of transitions, model coefficients and exact } p \\
\text { values not reported. } \\
-25-49 \text { year olds } \\
\text { Employment } \rightarrow \text { long term sick: No significant effect } \\
\text { Inactivity } \rightarrow \text { employment : Positive effect }(p<0.1) \\
\text { Unemployment } \rightarrow \text { long term sick: No significant effect } \\
-50-64 \text { year olds } \\
\text { Employment } \rightarrow \text { long term sick: Negative effect }(p<0.1) \\
\text { Inactivity } \rightarrow \text { employment, No effect. } \\
\text { Unemployment } \rightarrow \text { Long term sick: Positive effect }(p<0.1)\end{array}$ & $\begin{array}{l}\text { The authors concluded that the IWA made } \\
\text { transitions from inactivity into employment } \\
\text { more likely for } 25-49 \text { year olds. Amongst older } \\
\text { workers the IWA decreased flow from } \\
\text { employment into long term sick. However they } \\
\text { also found IWA increased flow from } \\
\text { unemployment into long term sickness, } \\
\text { therefore the IWA didn't contribute to overall } \\
\text { decrease in movements onto IB. Health status } \\
\text { and wages were not controlled for in the } \\
\text { analysis. }\end{array}$ & 12 \\
\hline $\begin{array}{l}\text { Faggio, G; } \\
\text { Nickell, S[40] }\end{array}$ & $\begin{array}{l}\text { Men age 25- } \\
54\end{array}$ & $\begin{array}{l}\text { Difference in } \\
\text { differences study } \\
\text { with ecological } \\
\text { data }\end{array}$ & $\begin{array}{l}\text { Weekly benefit rate (IB/IVB) paid to long term sick or } \\
\text { disabled with contributory benefit entitlements } \\
\text { between } 1982 \text { and } 1999 \text {. }\end{array}$ & $\begin{array}{l}\text { Linear regression of the log of the rate of benefits and } \\
\text { wages on non-employment } \\
\text { All: } 0.037(p=0.009) \\
\text { Low education: } 0.089(p=<0.001)\end{array}$ & $\begin{array}{l}\text { The authors concluded the level of incapacity } \\
\text { benefits was positively associated with male } \\
\text { inactivity and a much bigger impact was } \\
\text { observed for those without qualifications. They } \\
\text { find much larger effects associated with low } \\
\text { regional wages. Heatth status and labour market } \\
\text { conditions not controlled. }\end{array}$ & 10 \\
\hline $\begin{array}{l}\text { Disney R;Webb } \\
\text { S[38] }\end{array}$ & Men 18-69 & $\begin{array}{l}\text { Interrupted time } \\
\text { series with } \\
\text { ecological data } \\
\text { And cross } \\
\text { sectional analysis }\end{array}$ & $\begin{array}{l}\text { Average replacement rate from invalidity benefits } \\
\text { between1979 and - } 1984 \text {. The real value of benefits } \\
\text { increased has } \\
\text { this period. }\end{array}$ & $\begin{array}{l}\text { Linear regression of replacement rate (benefits/wages) on } \\
\text { probability of IVB receipt } \\
0.292 \text { ( } p<0.001) \\
\text { Also include a cross-sectional analysis of various factors on } \\
\text { employment, but this does not include disability benefits as } \\
\text { a independent variable }\end{array}$ & $\begin{array}{l}\text { The authors concluded that the trend in IVB } \\
\text { receipt was explained by the ageing of the } \\
\text { workforce, changes in the replacement rate, in } \\
\text { the health status of the workforce and in income } \\
\text { and housing tenure. However the dominant } \\
\text { variable was unemployment. They did not } \\
\text { control for health status, education or labour } \\
\text { market conditions in - in the time series analysis. }\end{array}$ & 9 \\
\hline $\begin{array}{l}\text { Brian Bell and } \\
\text { James } \\
\text { Smith;[39] }\end{array}$ & $\begin{array}{l}25-59 \text { year } \\
\text { old Men }\end{array}$ & $\begin{array}{l}\text { Time series study } \\
\text { with ecological } \\
\text { data }\end{array}$ & $\begin{array}{l}\text { Change in value of benefits between } 1984 \text { and } 2001 \\
\text { resulting from increasing benefit level s prior to the } \\
\text { introduction of the IWA in } 1995 \text { and a drop in benefit } \\
\text { levels for some age groups following the IWA. }\end{array}$ & $\begin{array}{l}\text { Regression of benefit level on labour force non- } \\
\text { participation } \\
\text { Elasticity=0.26 ( } \mathrm{p}=0.002) \text {, however controlling for separate } \\
\text { age trends reduced the coefficient and it became not } \\
\text { significant. }\end{array}$ & $\begin{array}{l}\text { The authors concluded that there was a sizable } \\
\text { effect on male labour market participation of } \\
\text { changes in benefit levels. This was particularly } \\
\text { the case for the least educated men. Did not } \\
\text { control for wages, health status or labour } \\
\text { market conditions. }\end{array}$ & 7 \\
\hline
\end{tabular}




\section{Studies investigating Swedish policy changes.}

Two studies from SwedenSweden $[41,45]$ investigated changes in sickness and disability insurance policies. Hesselius and Persson (2007) used longitudinal (panel) data to investigate the effects on long-term sickness absence of a 1998 reform to the Swedish national sickness insurance scheme. This allowed for additional compensation from collective insurance schemes to be paid on top of national sickness insurance payments after 90 days of sickness absence. They found that for people on long term sickness absence, this reform was associated with an average increase in the duration of sickness absence of 4.7 days (2\%) [41]. In the second study, Karlström et al (2008) used longitudinal data to investigate a 1997 change in the Swedish disability insurance scheme that abolished favourable treatment for people aged over 60 . It required applicants to change occupation or residence to find a suitable job, to undertake a more stringent medical test and to engage in rehabilitation. The study did not detect any effect from the reform on the employment of older men (aged 60-64)[45]. They did find, however, that the reform was associated with a decrease in transition from unemployment insurance to disability insurance, a higher transition from employment to sickness insurance, a lower transition from sickness insurance to disability insurance and increased persistence in sickness insurance. In other words, the reform resulted in people shifting between benefits and did not appear to result in increased employment. These two studies were rated through the validity assessment as having the most robust data and analytical approaches.

\section{Studies investigating policy changes in Norway.}

One study from Norway was included in the review (Bowitz, 1997). This investigated the effect of changes in the replacement rate in the Norwegian disability insurance scheme between 1971 and 1991. Over this period, average replacement rates rose in the late 1970s and were unchanged or declined slightly during the 1980s[42]. The study found no significant relationship between the replacement rate and the numbers of people claiming disability benefits. It concluded that increasing unemployment was more important than increasing benefit levels in explaining rising entry rates into disability benefits during this time period. 
Table 5. Studies on Swedish and Norwegian policy changes

\begin{tabular}{|c|c|c|c|c|c|c|}
\hline Author & $\begin{array}{l}\text { Populatio } \\
n\end{array}$ & Study type & $\begin{array}{l}\text { Description of policy under } \\
\text { analysis }\end{array}$ & $\begin{array}{l}\text { Result - regression } \\
\text { coefficient (p-value) }\end{array}$ & Comments & VA \\
\hline \multicolumn{7}{|l|}{ SWEDEN } \\
\hline $\begin{array}{l}\text { Patrik Hesselius and Malin } \\
\text { Persson[41] }\end{array}$ & $\begin{array}{l}\text { All } \\
\text { individuals } \\
\text { with } \\
\text { sickness } \\
\text { absence } \\
\text { spells of at } \\
\text { least } 19 \\
\text { days }\end{array}$ & $\begin{array}{l}\text { Differences in } \\
\text { Differences } \\
\text { approach using } \\
\text { panel data to } \\
\text { compare blue } \\
\text { collar workers with } \\
\text { government } \\
\text { workers who were } \\
\text { not affected by } \\
\text { policy change }\end{array}$ & $\begin{array}{l}\text { A } 1998 \text { policy change in the } \\
\text { national sickness insurance } \\
\text { programme that allowed blue } \\
\text { collar workers and municipal } \\
\text { workers to claim an additional } \\
10 \% \text { of wages through } \\
\text { compensation from collective } \\
\text { agreements on top of the } \\
\text { national insurance payments, } \\
\text { after } 90 \text { days of sickness } \\
\text { absence. Previously additional } \\
\text { payments were deducted from } \\
\text { national insurance. }\end{array}$ & $\begin{array}{l}\text { Linear regression of policy } \\
\text { change on duration of } \\
\text { sickness absence. } \\
4.66 \text { days ( } p=0.001)\end{array}$ & $\begin{array}{l}\text { The authors concluded that this policy resulted in an increase in the duration } \\
\text { of sickness absence, in this population by an average of } 4.7 \text { days. No } \\
\text { corresponding effect was found prior to the } 91 s t \text { day or after the } 360 \text { th day } \\
\text { in sickness absence. Health, education or occupation not controlled in the } \\
\text { analysis }\end{array}$ & 14 \\
\hline $\begin{array}{l}\text { Karlström,Anders; } \\
\text { Palme,Mărten; } \\
\text { Svensson,Ingemar[45] }\end{array}$ & $\begin{array}{l}\text { Male } \\
\text { workers } \\
\text { aged 60- } \\
64 .\end{array}$ & $\begin{array}{l}\text { Differences in } \\
\text { differences } \\
\text { approach using } \\
\text { panel data to } \\
\text { compare effect of } \\
\text { reforms on } 60-64 \\
\text { year olds to } 55-59 \\
\text { year olds }\end{array}$ & $\begin{array}{l}1997 \text { policy change in the } \\
\text { Swedish Disability Insurance } \\
\text { scheme, which abolished } \\
\text { favourable treatment for over } 60 \\
\text { year olds including requirement } \\
\text { to change occupation/ residence } \\
\text { to find suitable job, a more } \\
\text { stringent medical test and the } \\
\text { requirement to engage n } \\
\text { rehabilitation. }\end{array}$ & $\begin{array}{l}\text { OLS regression of various } \\
\text { transitions in and out of } \\
\text { employment } \\
\text { Employment } \rightarrow \text { non- } \\
\text { employment } \\
-0.0074(p>0.1) \\
\text { All states } \rightarrow \text { Disability } \\
\text { Insurance } \\
-0.0104(p>0.1) \\
\text { non-employment } \rightarrow \text { non- } \\
\text { employment } 0.01(p<0.05)\end{array}$ & $\begin{array}{l}\text { The authors concluded that it was not possible to detect any effect on } \\
\text { employment from the reform. There did however appear to be an } \\
\text { anticipation effect, in that there was an increased flow into disability } \\
\text { insurance when the reform was announced. This was } 2 \text { years before the } \\
\text { reform was actually implemented. } \\
\text { They did however find that the reform was associated with a decrease in } \\
\text { transition from unemployment insurance to disability insurance and, higher } \\
\text { transition from employment to Sickness insurance and lower transition from } \\
\text { Sickness insurance to Disability insurance as well as increased persistence in } \\
\text { Sickness insurance. In other words the reform resulted in people shifting } \\
\text { between benefit systems and not into the labour market. Level of disability, } \\
\text { wages and benefit level were not controlled for in the analysis }\end{array}$ & 14 \\
\hline \multicolumn{7}{|l|}{ NORWAY } \\
\hline Bowitz E[42] & $\begin{array}{l}\text { Men and } \\
\text { women } \\
16-66\end{array}$ & $\begin{array}{l}\text { A time series } \\
\text { approach using } \\
\text { ecological data }\end{array}$ & $\begin{array}{l}\text { Changes in the replacement rate } \\
\text { in the Norwegian disability } \\
\text { insurance scheme between } \\
\text { 1971-1991. Average replacement } \\
\text { rates rose in the late 1970s and } \\
\text { were unchanged or declined } \\
\text { slightly during the 1980s }\end{array}$ & $\begin{array}{l}\text { An error correction } \\
\text { weighted linear regression } \\
\text { analysing the effect of the } \\
\text { replacement rate on the } \\
\text { probability of entry into } \\
\text { disability benefits. } \\
0.17(p=0.16)\end{array}$ & $\begin{array}{l}\text { The authors concluded that unemployment was important in explaining } \\
\text { rising entry rates into disability benefit, but that there was less evidence for } \\
\text { the effect of increases in the replacement rate. No control for health status } \\
\text { or educational level. }\end{array}$ & 9 \\
\hline
\end{tabular}




\section{Discussion}

Our review sought to identify the evidence available from 5 OCED countries with highly developed social welfare systems, to determine the extent to which the generosity and eligibility requirements of disability benefit programmes affect labour market participation.

There was no clear evidence from these countries that changes in the eligibility requirements of disability benefits had a measurable impact on employment. Of the 5 studies that specifically addressed this issue, 1 from Canada found that relaxing eligibility was significantly associated with a decline in employment of older men[43], 2 papers from Canada found that some periods of relaxed eligibility were associated with a significant increase in employment $[34,46]$ and 2 papers from Canada[44] and Sweden[45] found no significant effect; importantly this included the Swedish paper that was rated as having the highest level of validity. Two papers from the UK assessed the impact of the Incapacity for Work Act which involved both a reduction in benefit levels and a tightening of assessment approach. These studies gave a mixed picture, one study demonstrated improved employment outcomes[47], whilst the other did not detect any effect[48]. Therefore we conclude that there is insufficient evidence to indicate whether changes in benefit eligibility requirements similar to those studied here will have an impact on the employment of people with disabilities and chronic Illness in well developed welfare states.

Of the 11 studies that investigated whether the generosity of disability benefits influenced labour market participation, 8 reported that benefit levels or benefit replacement rates had a significant negative association with measures of labour market participation [34-41]. Only one of these studies investigated the effect of benefit levels separately on the employment of women and this found no significant effect[46], the others only included men or were on mixed populations. These studies all have substantial validity issues, which we discuss in more detail below. The Swedish study that was assessed as being the most robust did however demonstrate a small but significant effect with an increase in benefit of up to $10 \%$ associated with a $2 \%$ increase in the duration of long term sickness [41]. Whilst several of the other studies in this review report much larger effects, there is some likelihood that the size and significance of these effects are attributable to other confounding factors and inappropriate statistical methods. We therefore conclude that whilst it is likely that at some level increased benefit generosity will reduce labour market participation, and that the majority of evidence reviewed here points in that direction, there is insufficient evidence of a high enough quality to determine the extent of that effect. 


\section{Limitations of the available evidence}

All of these studies rely on "natural policy experiments", arising from governments changing disability benefit schemes over time, or when schemes were administered differently in different jurisdictions as in Canada. As with other observational studies, we need first to assess whether the size of the effects observed could be attributable to confounding factors or could have occurred by chance.

Conventional economic analysis of welfare systems has been criticised for oversimplifying the relationship between participation in the labour market and financial incentives [8]. There are numerous interrelated factors that could influence whether a person developing a health problem will subsequently remain in or return to employment. To determine whether the reported results are actually the result of changes in disability benefits, these other factors need to be taken into account either in the study design or in the analysis. Potential confounding factors in these studies would include changes in labour market conditions, disability and workplace legislation,

rehabilitation interventions, as well as differences in individual characteristics such as educational level or health status. However many of the studies reviewed here had not fully taken this context into account. Four out of the 16 studies reviewed did not control for labour market conditions in their analysis [35, 39-40, 49]. Seven studies used aggregate (ecological) data in which individual characteristics cannot be adequately controlled for [34, 37-40, 42, 46]. Even those studies using individual data lacked sufficient controls for important individual confounders: all 16 studies were missing controls for one or more of the following variables; educational level, occupation, health status or wages.

It is recognised that these confounding issues can be partly overcome by using a "differences in differences" design and through using fixed effects models with longitudinal (panel) data[50]. Nine of the studies in this review [34-35, 40-41, 43-46, 49] used a difference in difference approach. Four of the studies reviewed used longitudinal (panel) data [41, 45, 47-48], and only 2 of used both [41, 45].

Fixed effects models will however only control for unobserved individual effects if these do not vary over time. Difference in difference designs, where one group has been affected by a policy change whilst another has not, will still be susceptible to an imbalance in characteristics between these two groups particularly if this results in different trends over time in the outcome. 
The statistical techniques used by many of the studies in this review have been criticised widely in the econometric literature [51-53]. In particular where they have not taken into account serial and spatial correlation in the dependant variable [51-52]. Bertrand et al. (2004) demonstrate that this issue could result in difference-in-difference studies reporting a significant effect $45 \%$ of the time when in fact there is no effect[52]. Nine of the studies in this review, [34-39, 42-43] had not taken one or other of these issues into account and therefore will have under-estimated the standard error of the effect. The two studies from Sweden $[41,45]$ were rated as having the highest validity because they were the only studies to use longitudinal (panel) data, a difference in differences approach and an appropriate statistical technique. Given the threats to the validity of many of the studies in this review conclusions are necessarily limited and indicate that there is a lack of evidence of a high enough quality to indicate the extent to which these policies will increase labour market participation of people with chronic illness and disabilities.

\section{Policy implications}

There are various potential reasons why we found no clear evidence that changes in benefit eligibility requirements influenced employment. This may have resulted from the methodological issues discussed but it is also possible that there is actually no effect from these policies. One possible reason for a lack of effect, suggested by some papers in this review, is that changes in the eligibility structure for one benefit may result in movement into other benefit schemes rather than into the labour marketmarket $[45,47]$. For example Karlstrom and Palme (2008) show that changes in the assessment requirements for disability benefits in Sweden resulted in increased persistence of people on sickness and unemployment benefits, but no increase in employment[45]. This indicates that changes to disability benefits need to be coordinated with developments in other welfare benefit schemes. The aim should be to increase employment rather just reducing the number of people on benefits.

Whilst we did not find sufficient evidence of a high enough quality to indicate the extent to which changes in benefit generosity affect employment, several studies indicated that wage levels and the level of unemployment, are potentially more important influences on the employment of people with disabilities. Three of the studies from the UK and Canada report that the low wages of jobs available was a more important predictor of decreased employment than the level of disability benefits [36, 39-40]. The level of unemployment at a regional and national level is also recognised as an important determinant of the numbers of people on disability benefits in two papers from the UK 
and Norway [38, 42], with higher numbers on disability benefits associated with higher levels of unemployment.

The relationship between the level of wages and the structure of the disability benefit system in a country has important implications for work incentives and the differential effect of benefit levels on different socioeconomic groups. Norway, Denmark and Sweden are characterised by high minimum wages and generous disability benefits. High minimum wages in these countries may give strong incentives to work particularly for people with low social status, overriding the disincentive effects of high benefits. In Norway and Sweden benefit levels are dependent on previous earnings; this means that replacement rates (i.e the proportion of wages that would be replaced by benefits) are at a similar level for people on low wages as for those on higher wages. In countries with flat rate benefits such as the UK, Denmark and to a lesser extent Canada, the replacement rate will be higher for low wage earners than for higher earners. The disincentive effects of disability benefits are therefore likely to be greater for less skilled socioeconomic groups in those countries with flat rate benefits, particularly if wage levels for unskilled labour are also low. This may explain why two of the studies from the UK found that the negative effect of benefit levels on employment was larger for people with no qualifications[39-40].

In all five countries included in this review the employment rates of people with a chronic illness or disability decrease steeply with decreasing socioeconomic status [6-7]. The evidence presented here suggests that a combination of low wages for unskilled labour, high unemployment in disadvantaged areas and flat-rate disability benefits is likely to exacerbate this level of inequality. Interventions which may be influential would include those which increase the number of jobs that are accessible to people with disabilities and increase their wages either through subsidies or minimum wage legislation.

Before policy makers consider lowering and/or restricting access to disability benefits, on the assumption that it will increase employment amongst people with disabilities, they need to weigh up the potential benefits that may result from this policy, against its potential negative consequences. This review demonstrates that there is lack of high quality evidence of the extent to which reducing benefit levels will increase employment in countries with well developed welfare states. The level of gain from reducing benefits is largely unknown. The negative consequences have also not been assessed, but would potentially include increased poverty for people who already have health problems, possibly exacerbating health inequalities. Whilst changing benefit levels may affect the 
employment of some claimants at the margins, the consequences of this, in terms of loss of income, affects all claimants. If the employment effects are found to be small and leave more vulnerable groups such as people with mental health problems on reduced benefits, the negative consequences may outweigh the gains made in increasing employment.

Future evaluations of these policies need to determine the extent to which they impact, not only on the employment of people with chronic illness and disabilities, but also on their income, social inclusion and health, as well as any differential impact across health conditions and social groups.

\section{Funding}

SC and MMW were funded by the Public Health Research Consortium, which is funded by the Department of Health Policy Research Programme. The views expressed in the publication are those of the authors and not necessarily those of the DH. BB and LN????

\section{Appendix 1. Major disability benefit changes in countries included in study}

\begin{tabular}{|c|c|}
\hline Country & Major Reforms of Disability Benefits \\
\hline Canada & $\begin{array}{l}\text { 1973- Benefits in the QPP programme increased by } \$ 50(C A D) .[49] \\
1984 \text {-QPP introduced early retirement option.[49] } \\
1987-\text { CPP doubled the value of the flat-rate component of the benefit to a level equal to } \\
\text { that paid by the QPP, relaxed the contributory eligibility rule and introduced early } \\
\text { retirement option. [34, 46, 54] } \\
1989 \text { - CPP policy directive allowing non medical factors such as the regional unemployment } \\
\text { rate to be taken into account when assessing claims[54] } \\
\text { 1992- CPP allowed for retrospective claims for benefits to be determined some time after } \\
\text { the date of onset of disability } \\
\text { 1993- QPP changed their requirement for being unable to work from "any job" to "usual } \\
\text { job" and relaxed contribution requirements } \\
\text { 1995- A more stringent set of medical adjudication guidelines adopted in the CPP. } \\
\text { 1995-A reversal of previous policy in the CPP allowing non medical factors such as the } \\
\text { regional unemployment rate to be taken into account when assessing claims. } \\
\text { 1995 -CPP Expands work test requirements to include 55-64 year olds. } \\
\text { 1998-CPP changes contribution requirements and increases number of years of earnings } \\
\text { used to calculate earnings related portion of benefit. }\end{array}$ \\
\hline UK & $\begin{array}{l}1971 \text { - Invalidity Pension and Invalidity Allowance (together known as Invalidity Benefits } \\
\text { (IVB) contribution-based, income-replacement benefit introduced. } \\
1975 \text { - Introduction of Non-Contributory Invalidity Pension (NCIP) at lower rate than IVB } \\
\text { (housewives ineligible) } \\
1984 \text { - NCIP replaced with Severe Disablement Allowance. }\end{array}$ \\
\hline
\end{tabular}




\begin{tabular}{|c|c|}
\hline & $\begin{array}{l}\text { 1980- Invalidity Benefits linked to prices rather than being up-rated with earnings as they } \\
\text { had been previously. } \\
1986 \text { - Income Support replaces Supplementary Benefit and includes extra cost Disability } \\
\text { Premium[55] } \\
\text { 1995- Incapacity for Work Act replaces IVB with Incapacity Benefit (IB). IB was not available } \\
\text { to people over state pension age, eligibility conditions were tighter, those claiming IB no } \\
\text { longer received an additional pension based on earnings history, as a result the benefit level } \\
\text { for older workers reduced by about 37\%[39] } \\
\text { 1999- Contribution conditions modified, additional information required on ability to work, } \\
\text { income from private pensions taken into account in assessing amount of benefit to be paid } \\
\text { out. } \\
2001 \text {-Severe Disablement Allowance closed to new claims. } \\
2008-\text { Welfare Reform Act replaces IB with Employment Support Allowance for new } \\
\text { claimants, this includes a more stringent work capability assessment and two-tier benefit } \\
\text { with those deemed to be capable of work related activity will receive lower benefits than } \\
\text { those judged unable to work conditional upon them undertaking work-related activity. [56] }\end{array}$ \\
\hline Sweden & $\begin{array}{l}\text { 1987-Increase in sickness benefit replacement rate to } 90 \% \text { of earnings for all claims } \\
1991-\text { Reduction in sickness benefit level to } 75 \% \text { in the first three days. } \\
1992 \text {-Reduction in sickness benefit level to } 80 \% \text { after day } 90 \text {. } \\
1993-\text { Reduction in sickness benefit level to } 70 \% \text { after the first year. } \\
\text { Second half of the } 1990 \text { s compensation rates increased again, offering } 90 \% \text { until the end of } \\
\text { the first year and } 80 \% \text { thereafter. } \\
\text { 1995-Tougher rules for sickness certification introduced } \\
\text { 1997- Policy change in the disability insurance scheme, which abolished favourable } \\
\text { treatment for over } 60 \text { year olds, introducing the requirement to change occupation or } \\
\text { residence to find suitable job as well as a more stringent medical test and the requirement } \\
\text { to engage n rehabilitation. } \\
1998 \text { - A policy change in the sickness insurance programme that allowed blue collar } \\
\text { workers and municipal workers to claim an additional } 10 \% \text { of wages through compensation } \\
\text { from collective agreements on top of the national insurance payments, after } 90 \text { days of } \\
\text { sickness absence. } \\
2003 \text { Sickness and disability benefits merged: claimants aged under-30 receive 'activity } \\
\text { compensation' only paid for a maximum of three years, over-30s receive 'sickness } \\
\text { compensation' that can be permanent } \\
2007-\text { New guidelines introduced for granting sick leave certificates by GPs } \\
2008-\text { Reduction in sickness benefit to } 80 \% \text { of prior earnings for the first year, } 75 \% \text { for the } \\
\text { second year payable for a maximum of } 550 \text { days. [5, } 45,57-59 \text { ] }\end{array}$ \\
\hline Norway & $\begin{array}{l}1988 \text { the introduction of a medical Certificate system at } 8 \text { weeks of sickness absence.[60] } \\
1993 \text { Second medical reassessment introduced at } 12 \text { weeks } \\
1970 \text { 's-1980's-On average, replacement rates rose in the late } 1970 \text { s and were unchanged or } \\
\text { declined slightly during the } 1980 \text { s.[28] } \\
\text { 1991- Eligibility criteria tightened and level of benefit reduced [60-61] } \\
\text { 1998- Minimum pension increased by } 10 \% \text {, age limit raised from } 16 \text { to } 18 \text { years old medical } \\
\text { requirements sharpened for young disabled[62] } \\
2000-\text { Requirement for having gone through rehabilitation increased[62] } \\
2004-\text { Introduction of temporary disability benefit, and stricter evaluation of the functional } \\
\text { capacity of the people on sick leave, including sanctions on GPs who do not comply with the } \\
\text { new rules. }\end{array}$ \\
\hline Denmark & $\begin{array}{l}\text { Prior to } 2003 \text { - Disability benefit level depended degree of disability, family status and age. } \\
2003 \text { - A new disability pension scheme consolidated this scheme into one benefit payable } \\
\text { at a flat rate which is around half of the gross average wage. The partial benefit for partial }\end{array}$ \\
\hline
\end{tabular}




\begin{tabular}{|l|l|}
\hline disability was abolished altogether. The reform also included a change in the assessment \\
criterion so that a person is now assessed as to whether they can support themselves \\
through any work including a subsidised flex-job. \\
$\begin{array}{l}2005 \text { - New medical certificates for sickness certification were introduced with a focus on } \\
\text { the person's ability to function (certificates remain non-statutory)[63]. }\end{array}$ \\
\hline
\end{tabular}

\section{Appendix 2: Databases searched}

1. British Humanities index $\mathrm{BHI}$

2. MEDLINE

3. Scopus Business and Economics

4. Scopus natural sciences

5. Sociological Abstracts

6. International Bibliography of the Social Sciences

7. Database of Abstracts of Reviews of Effects

8. Cochrane database for systematic reviews

9. Social Sciences Index

10. Proquest dissertations and thesis

11. Econpapers

12. System for Information on Grey Literature in Europe Archive

13. Web of Science

Websites

1. International Labour Organisations

2. OECD

3. Department for work and Pensions

4. Her Majesties Revenue and Customs

5. Institute for Fiscal Studies

6. National Institute for Economic and Social Research.

7. The Institute for Employment Research.

8. Centre for Economic Policy Research

9. Danish National Centre for Social Research.

10. Stockholm University's Department of Economics Working papers.

11. Sweden's National Institute of Economic Research.

12. The Institute for Labour Market Policy Evaluation

Appendix 3.

Validity Assessment 


\begin{tabular}{|c|c|c|}
\hline Criteria & Rationale & Score \\
\hline $\begin{array}{l}\text { Unit of } \\
\text { analysis }\end{array}$ & $\begin{array}{l}\text { First, whether the unit of analysis was aggregate } \\
\text { (ecological), individual or repeated measures on } \\
\text { the same individuals (panel). Panel data was seen } \\
\text { as being the most robust as it allows for } \\
\text { unmeasured confounding factors to be accounted } \\
\text { for where these do not vary within individuals } \\
\text { over time. Ecological studies were seen at the } \\
\text { least robust as ecological bias can occur where } \\
\text { aggregate data are used to make inferences about } \\
\text { individuals.[64] Second, in terms of the } \\
\text { comparison approach used in the analysis. }\end{array}$ & $\begin{array}{l}\text { 3- Longitudinal (panel) data } \\
\text { 2-Individual data } \\
\text { 1-Ecological (aggregate data) }\end{array}$ \\
\hline $\begin{array}{l}\text { Comparison } \\
\text { approach }\end{array}$ & $\begin{array}{l}\text { Studies either compared cross sectional } \\
\text { differences in disability benefits, changes over } \\
\text { time or a combination of both using a difference in } \\
\text { differences approach. Cross sectional comparisons } \\
\text { will be particularly susceptible to unmeasured } \\
\text { sources of confounding. Studies that look at } \\
\text { changes in the same group over time will } \\
\text { overcome this to a certain extent; however the } \\
\text { results will be at risk of being influenced by other } \\
\text { secular trends. The most robust approach will be } \\
\text { where a policy has changed over time for one } \\
\text { group and this is compared with another group } \\
\text { that is unaffected by the change (a difference in } \\
\text { differences approach). }\end{array}$ & $\begin{array}{l}\text { 3-Difference in Differences } \\
\text { 2-Interupted time series } \\
\text { 3-Cross sectional }\end{array}$ \\
\hline $\begin{array}{l}\text { Selection } \\
\text { and } \\
\text { response } \\
\text { bias }\end{array}$ & $\begin{array}{l}\text { Assessment of the level of selection and response } \\
\text { bias, based on information reported on data } \\
\text { sources. No studies reported response rates or } \\
\text { formally assessed response or selection bias. Most } \\
\text { studies used recognised national surveys. }\end{array}$ & $\begin{array}{l}\text { 3- Random sample/ Nationally } \\
\text { recognised survey } \\
\text { 2-Non random sample but } \\
\text { evidence that it is comparable } \\
\text { 1- Non random sample from } \\
\text { administrative system of } \\
\text { programs without universal } \\
\text { coverage. }\end{array}$ \\
\hline
\end{tabular}




\begin{tabular}{|c|c|c|}
\hline Confounding & $\begin{array}{l}\text { Whether potential confounders were adequately } \\
\text { adjusted for in the analysis (Age, Sex, Health } \\
\text { status, Labour market conditions, wage, education } \\
\text { or occupation. }\end{array}$ & $\begin{array}{l}\text { 3- All major confounders } \\
\text { included in analysis } \\
\text { 2-Missing }<3 \text { confounders } \\
\text { 1-missing }>2 \text { confounders }\end{array}$ \\
\hline Analysis & $\begin{array}{l}\text { The likelihood of the analysis resulting in biased } \\
\text { estimates was assessed. This included looking at } \\
\text { the sample size and whether an appropriate } \\
\text { statistical technique had been used. In particular } \\
\text { several studies had not adequately adjusted for } \\
\text { the spatial clustering and serial correlation in the } \\
\text { data. Often multiple model specifications are } \\
\text { presented each with different sets of covariates } \\
\text { without a systematic approach to identify the } \\
\text { most appropriate covariates to include in the final } \\
\text { model [65]. }\end{array}$ & $\begin{array}{l}\text { 3- large sample size and an } \\
\text { appropriate statistical } \\
\text { technique was used } \\
\text { 2-Either an inappropriate } \\
\text { statistical technique was used } \\
\text { or the sample size was small. } \\
\text { 3.-Both an inappropriate } \\
\text { statistical technique was used } \\
\text { and the sample was small. }\end{array}$ \\
\hline
\end{tabular}

Appendix 4. Summary of search stategy

Policy (change/difference/reform/eligib*/uneligib*/qualify*/entitl*/generosity/screen*/ condition* AND/benefit*/insurance/income replacement/pension*/ compensation/welfare/social security),

Population (sickness/disab*/chronic/injur*/accident/illness/)

Outcome Labour/labor/work/force/involve*/participat*/unemployment/employment). 


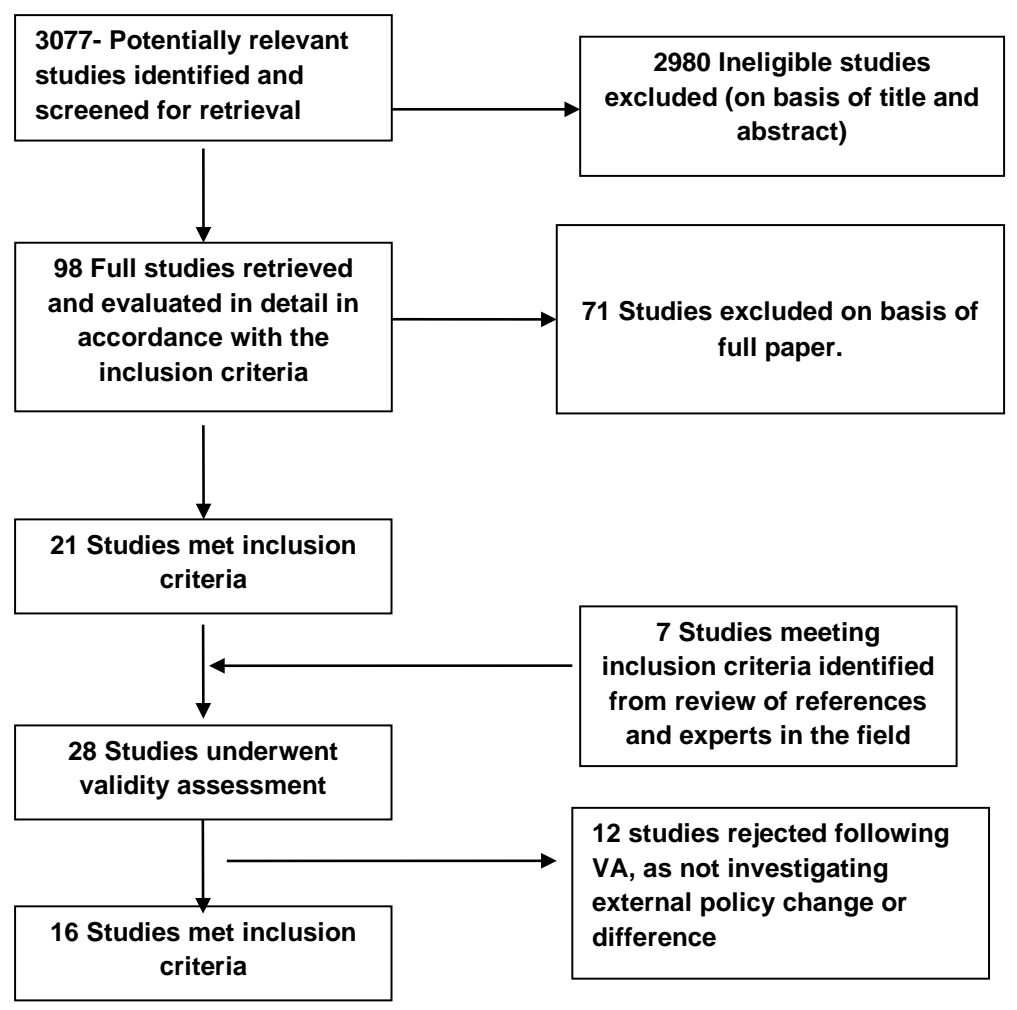

Figure 1 Flow chart for searches and study selection

A full search strategy is available from the author's on request

References

1 OECD. Transforming Disability into Ability Policies to Promote Work and Income Security for Disabled People. Paris: OECD 2003.

2 OECD. Sickness, Disability and Work (Vol. 1): Norway, Poland and Switzerland. Paris: OECD 2006.

3 OECD. Sickness, Disability and Work (Vol. 2): Australia, Luxembourg, Spain and the United Kingdom. Paris: OECD 2007.

4 OECD. Sickness, Disability and Work (Vol. 3): Denmark, Finland, Ireland and the Netherlands. Paris: OECD 2008.

5 OECD. Sickness, Disability and Work: Breaking the Barriers SWEDEN: Will Reforms Really Make it. 2009. 

fate of women with chronic illness in contrasting policy environments--Sweden and Britain. IntJ Health Serv 2003;33:199-217.

7 Burstrom B, Whitehead M, Lindholm C, et al. Inequality in the social consequences of illness: how well do people with long-term illness fare in the British and Swedish labor markets? IntJ Health Serv 2000;30:435-51.

8 Atkinson A, Morgensen G, eds. Welfare and Work Incentives: A North European Perspective. Oxford: Oxford University Press 1993.

9 Parsons DO. The Decline in Male Labor Force Participation. The Journal of Political Economy 1980;88:117-34.

10 Black D, Daniel K, Sanders S. The Impact of Economic Conditions on Participation in Disability Programs: Evidence from the Coal Boom and Bust. The American Economic Review 2002;92:27-50.

11 Autor DH, Duggan MG. The Rise In The Disability Rolls And The Decline In Unemployment*. Quarterly Journal of Economics 2003;118:157-205.

12 Haveman RH, Wolfe BL. The Decline in Male Labor Force Participation: Comment. The Journal of Political Economy 1984;92:532-41.

13 Bound J. Health and Earnings of Rejected Disability Insurance Applicants. American Economic Review 1989;79:482-503.

14 Bound J, Waidmann T. Accounting for Recent Declines in Employment Rates among

Working-Aged Men and Women with Disabilities. The Journal of Human Resources 2002;37:231-50.

15 Bound J. The Health and Earnings of Rejected Disability Insurance Applicants: Reply. The

American Economic Review 1991;81:1427-34.

16 Affairs MotlaS. Consolidation Act on Social Pensions. 2004.

17 Duncan M. WHY HAVE UK DISABILITY BENEFIT ROLLS GROWN SO MUCH? Journal of

Economic Surveys 2008;22.

$18 \quad$ AlltheWeb. 2008.

19 Rice N, Godfrey C, Slack R, et al. A systematic review of the effects of price on the smoking behaviour of young people. York 2009.

20 Downs SH, Black N. The feasibility of creating a checklist for the assessment of the methodological quality both of randomised and non-randomised studies of health care interventions. Journal of Epidemiology and Community Health 1998;52:377-84.

21 Wells G, Shea B, O'Connel D, et al. The Newcastle-Ottawa Scale (NOS) for assessing the quality of nonrandomized studies in meta-analysis [manuals and scales]. [internet]. 2008.

22 McMaster U. Effective Public health Parcatice Project. Quality assessment tool for quantitative studies. 2008.

23 Campolieti M, Gunderson M, Krashinsky H. Labor Supply Decisions of Disabled Male Workers. Journal of Labor Research 2007;no. 3, Summer 2007, pp. 502-14:14.

24 Butler RJ, Baldwin ML, Johnson WG. The Effects of Worker Heterogeneity on Duration Dependence: Low-Back Claims in Workers Compensation. Review of Economics and Statistics;no. 4, November 2001, pp. 708-16:16.

25 Dahl SA, Nilsen OA, Vaage K. Work or Retirement? Exit Routes for Norwegian Elderly. Applied Economics 2000;no. 14, November 2000, pp. 1865-76:76.

26 Butler RJ, Johnson WG, Baldwin ML. Managing Work Disability: Why First Return to Work Is Not a Measure of Success. Industrial and Labor Relations Review;no. 3, April 1995, pp. 452-69:69.

27 Hyatt DE. Work disincentives of workers' compensation permanent partial disability benefits: Evidence for Canada. Canadian Journal of Economics-Revue Canadienne D Economique 1996;29:289-308.

28 Bratberg E. Disability Retirement in a Welfare State. Department of Economics, University of Bergen 1999.

29 Molho I. A Disaggregate Model of Flows onto Invalidity Benefit. Applied Economics 1989;21:237-50. 
30 Molho I. Going onto invalidity benefit: a study for women (1977/78â€“1983/84). Applied Economics 1991;23:1569-77.

31 Lynch M. The Duration of Invalidity Benefit Claims: A Proportional Hazard Model. Applied Economics 1991;23:1043-52.

32 Fenn PT, Vlachonikolis IG. Male Labour Force Participation Following Illness or Injury.

Economica 1986;53:379-91.

33 Brinch C. The effect of benefits on disability uptake. Discussion Papers, Statistics Norway, Research Department 2009;576.

34 Campolieti M. The Canada/Quebec pension plan disability program and the labor force participation of older men. Economics Letters 2001;70:421-6.

35 Gruber J. Disability Insurance Benefits and Labor Supply. Journal of Political Economy 2000;no. 6, December 2000, pp. 1162-83:83.

36 Harkness J. Labor-Force Participation by Disabled Males in Canada. Canadian Journal of Economics-Revue Canadienne D Economique 1993;26:878-89.

37 Maki DR. The Economic Implications of Disability Insurance in Canada. Journal of Labor Economics 1993;1:69.

38 Disney R, Webb S. Why Are There So Many Long Term Sick in Britain? Economic Journal 1991;no. 405, March 1991, pp. 252-62:62.

39 Bell B, Smith B. health, disability insurance and labour force participation. Bank of England 2004.

40 Faggio G, Nickell S. Inactivity Among Prime Age Men in the UK. CEP Discussion Paper, Centre for Economic Performance 2005;673.

41 Hesselius $\mathrm{P}$, Persson $\mathrm{M}$. Incentive and spill-over effects of supplementary sickness

compensation. Working Paper- The Institute for Labour Market Policy and Evaluation 2007;16.

42 Bowitz E. Disability Benefits, Replacement Ratios and the Labour Market. A Time Series Approach. Applied Economics 1997;29:913-23.

43 Campolieti M. Disability Insurance Eligibility Criteria and the Labor Supply of Older Men. Economics Bulletin 2003;no. 3, 2003, pp. 1-7:7.

44 Campolieti M, Goldenberg J. Disability Insurance Denial Rates and the Labor Force Participation of Older Men and Women in Canada. Atlantic Economic Journal 2007;no. 1, March 2007, pp. 59-75:75.

45 Karlstrom A, Palme M, Svensson I. The Employment Effect of Stricter Rules for Eligibility for DI: Evidence from a Natural Experiment in Sweden. Research Papers in Economics, Stockholm University, Department of Economics series 2008;3.

46 Campolieti M. Disability insurance and the labour force participation of older men and women in Canada. Canadian Public Policy-Analyse De Politiques 2001;27:179-93.

47 Clasen J, Davidson J, Granssmann H, et al. Non-Employment and the Welfare State: The United Kingdom and Germany Compared. Journal of European Social Policy 2006;no. 2, pp. 134-154, May 2006:154, May.

48 Disney R, Emmerson C, Wakefield M. III health and retirement in Britain: a panel data based analys. Institute for Fiscal Studies- Working Papers 2003;2.

49 Campolieti M. Disability insurance benefits and labor supply: Some additional evidence. Journal of Labor Economics 2004;22:863-89.

50 Skrondal A, S R-H. Multilevel and Related Models for Longitudinal Data. In: Leeuw J, Meijer E, eds. Handbook of Multilevel Analysis,. New York Springer 2008.

$51 \quad$ Moulton BR. An Illustration of a Pitfall in Estimating the Effects of Aggregate Variables on Micro Unit. The Review of Economics and Statistics 1990;72:334-38.

52 Bertrand M, Duflo E, Mullainathan S. How Much Should We Trust Differences-in-Differences Estimates?*. Quarterly Journal of Economics 2004;119:249-75.

53 Donald S, Lang K. Inference with Difference-in-Differences and Other Panel Data. The Review of Economics and Statistics 2007;89:221-33. 
54 (HRSDC) HRaSDC. Evaluation of the Canada Pension Plan (Disability Component) Final Report Ottowa 1996.

55 Burchardt T. The evolution of disability benefits in the UK: Re-weighting the basket London: Centre for Analysis of Social Exclusion 1999.

56 DWP DfWaP. No one written off:reforming welfare to reward responsibility. London 2008.

57 Pettersson-Lidbom P, Skogman P. Temporary Disability Insurance and Labor Supply:

Evidence from a Natural Experiment. 2006.

58 Henrekson $M$, Persson $M$. The effects on sick leave of changes in the sickness insurance system. Journal of Labor Economics 2004;22:87-113.

59 Johansson P, Palme M. Do economic incentives affect work absence? Empirical evidence using Swedish micro data. Journal of Public Economics 1996;59:195-218.

60 Dahl E. Important policy initiatives in Norway since 1990. Unpublished Working Paper 2007.

61 Claussen B. Rehabilitation efforts before and after tightening eligibility for disability benefits in Norway. International Journal of Rehabilitation Research 1997;20:139-48.

62 Holen D. It Aint Neccessarility So- A Cautionary Note Regarding Time Trends in Disability. Oslo: University of Oslo 2007.

63 Kristina J, John Sahl A, Sigurd M, et al. Controlling sickness absence: A study of changes in the Danish sickness absence legislation since 1973. Health policy (Amsterdam, Netherlands) 2008;86:109-18.

64 Greenland S. Ecologic versus individual-level sources of bias in ecologic estimates of contextual health effects. International Journal of Epidemiology 2001;30:1343-50.

65 Greenland S. Modeling and variable selection in epidemiologic analysis. American Journal of Public Health 1989;79:340-7. 